\title{
CONTENT AND LANGUAGE INTEGRATED TEACHING TO UKRAINIAN UNIVERSITY STUDENTS MAJORING IN ECONOMICS
}

\author{
Svetlana Bodnar \\ Odessa Institute of Trade and Economics of Kyiv National University of Trade and Economics, \\ Odessa, Ukraine \\ sv.bodnar@ukr.net
}

\begin{abstract}
The article discloses the problem of content and language integrated teaching to Ukrainian university students majoring in economics. The characteristics of the integrated teaching are presented. Nowadays pedagogical integration can be traced in all its forms: in interconnection of actions concerning youth education and upbringing; in interconnection of content of different subjects teaching, moreover not only related subjects (such as mathematics and physics) but so-called unconnected subjects (computer sciences and foreign languages); in interconnection of different activities as to the major subject learning. Pedagogical integration is realised by creating "practical synthesis", it means: joining the content of related subjects into one academic discipline; applying similar methods and techniques of teaching synthesised subject; emerging organisational forms of teaching different subjects into one organisational-methodic unity which functions in one educational process. The peculiarities of the integrated teaching economic subjects by means of a foreign language are highlighted in the article. Professional knowledge and skills that Ukrainian students majoring in economics are to master both in the native and in the foreign languages for professional material application into practice are described. The methods of integrated teaching economic subjects by means of a foreign language have been introduced. The article presents the model of stage-by-stage realisation of the integrated teaching two kinds of activities (professional and foreign language) with the description of the interconnected (synthetized) components of the teaching process.
\end{abstract}

Keywords: integrated teaching; professional activity; foreign language speech activity; economic subjects; students majoring in economics.

\section{Introduction}

Social, economic, political and cultural changes in Ukraine, its integration into the world educational environment, implementation of the UNESCO recommendations as for the competent specialist training are impossible without personal and professional development of a specialist who is able to adapt to multicultural, multilingual environment for the realisation of personal and professional needs and to work in a complete harmony with the international community. And in its turn, this is impossible without achieving a high level of foreign language mastering in the process of professional activity. In the government strategic documents such as: the Law of Ukraine "On Higher Education" (2014), the "National Education Development Strategy for the period 2012-2021", the "Project of Concept of Ukraine Education Development during 2015-2025" it is emphasised on training competitive specialists in the economic sphere who are able to speak fluently a foreign language as a means of international communication, to conduct oral and written business negotiations with foreign partners, to fill in the forms of financial documents, to make financial agreements/reports, to discuss financial and economic issues taking into account current trends of economy development and to improve professional knowledge by means of reading a professional literature in a foreign language.

In order to provide this opportunity to the Ukrainian specialists we suggest bringing together the processes of mastering professional and foreign language speech activities, thus creating the simultaneous acquisition of knowledge and the development of skills in two kinds of activities: professional and foreign language, it means to teach future professionals to carry out their professional work in a foreign language.

The problems of integrated teaching different disciplines are under consideration of many scientists. The main ideas of the integrative approach in the educational process were highlighted in the works of pedagogy founders (Jan Amos Komenský, Johann Heinrich Pestalozzi, Konstantin Ushinsky). Later these ideas found their way in the works of the Ukrainian and foreign scholars. For example, the works of Krajewski (2007), Petrovsky (1995), Talyzina (1984) dealt with the pedagogy integration into the other sciences. Lednev (1989) investigated the ways of integration into the content of education. Fedoretc (1989) researched integration in the teaching organisation.

The methodological principles of the subject and procedural kinds of integration were the subject of research of many scholars (Bezrukova, 1990; Honcharenko, 1994; Maximova, 1981; Martynova, 2010; Tyunnikov, 1988; Zverev, 1981; Zyazyun, 2008; Clark \& Hannon, 2006; Jennings, 1997; Klein, 1996; Walker, Welch \& Wright, 1998; and others).

The tendency of different subjects integration into one unity has been increased lately. Many contemporary Ukrainian (Martynova \& Dobrovolska, 2011; Mytnyk, 2014; Popel, 2015; Tarnopolsky \& 
Kornieva, 2013; Levchik, 2014; etc.) and foreign (Doraisamy \& Radhakrishnan, 2013; Shi Ying, 2016; Jamkar, Yemul \& Singh, 2016; Toppo et al., 2016) researchers have started to work in this direction. Their works are devoted to various aspects of integration: from the identification of the general laws of this process in education to the consideration of the peculiarities of definite subjects integration. However, the idea of integrated teaching students majoring in economics has not received special attention yet.

The aim of our research is to define the essence, content and stages of language integrated teaching to Ukrainian university students majoring in economics; to single out the synthesised elements of the integrated educational process. The object of the research is the professional training of students majoring in economics, and the subject is the process of integrated teaching students majoring in economics the professional and foreign language speech activities.

\section{Concept analysis}

First of all, it should be noted that the concept "professional training" is interpreted by us as a system of knowledge and skills aimed at developing individual professional readiness to perform professional actions and at developing professional skills. And "professional training of future economists" is defined as a conscious guidance on future profession, which appears in the predictable future economists' activity with colleagues, partners, clients, customers, CEOs that helps to solve economic problems, to find the ways of settling and overcoming crisis, to work out the strategies of enterprises development, to solve production issues, to make decisions, to influence the final results of the negotiations, meetings, business talks and takes into consideration cultural factors of economic sector. Besides it should be marked that professional training means not only learning the subject as a specialty, but also mastering the subject in a foreign language.

This situation leads us to the idea of the necessity of creation the integrated educational courses of economic subjects and foreign language subjects. Such integrated courses are going to be lectured by the foreign language teachers who will acquaint students with the material identical to that one which was studied in the economic subjects in the native language. As a result, there will be a synthesis of two educational processes into a common procedural unity, allowing simultaneous acquisition of knowledge and development of skills in two kinds of activities: professional and foreign language ones.

First of all, there is a need to consider the concept "integration" in detail. The term "integration" derives from the Latin word "integration" meaning "restoration"; it is a combination of some elements into one unity. One of the first definitions of modern pedagogical integration, which goes back to 1980-1990, belongs to Zverev \& Maximova (1981):

"Integration is a process and result of the creation of interconnected, integral unity. In the process of education, integration is realised by merging in one synthesized course (topic, subject section of the program) the elements of different subjects; merging scientific concepts and methods of different disciplines into the general scientific concepts and methods of cognition; summing up the fundamentals of sciences in solving interdisciplinary educational problems.” (p. 87)

Generally, the concept "integration" is defined by scholars as a combination of several subjects into one discipline in which scientific concepts are linked by a common sense and teaching methods (Tyunnikov, 1988). As reported by the doctor of sciences in pedagogy Sova (2005), integration process is an interdisciplinary movement of knowledge to the integrity that involves systematic studying the object, and appears the logical result of changes in any of interacting systems of knowledge and is a source of appearing new trends to their integration (p. 14). According to Popel (2015), the structure of integrated teaching process includes the acquisition of integrated conceptual knowledge, integrated skills, integrated prespeaking language skills, integrated speech skills.

Most scientists-philosophers point out such sides of integration: integration is depicted as a process of making connections between separate elements, that leads to a certain unity (Kondakov, 1975; Levin, 1987; Ursul, 2004); a state of interconnection, interdependence of parts of a united system (Afanasyev, 1990; Kedrov, 1984); a result of interaction of system elements leading to their full combining and appearing of a new "integrative qualities" (Markaryan, 2004; Fedoseev, 1986).

We share the standpoint of Martynova (2010) who considers an integrated teaching as a synthesis of two educational processes in a common procedural unity, allowing the simultaneous acquisition of knowledge and development of skills in two types of activities: professional and foreign language ones. Integrated skills involve the ability to study an integrated course on the basis of foreign language material with a dominant focus on the content of this course and controlling attention paid to a foreign language speech activity (p. 82). While integrating the parts of related subjects into each other and into corresponding parts of the key subject, a new megadiscipline, which should be studied in the same educational process, appears. It means that: 
1) the educational process will apply to the category of "monoprocesses", these are the processes which have identical goals; identical subject content (though integrated); identical components of educational content: knowledge and skills; identical methods and teaching aids; common methods of monitoring and evaluation of teaching results;

2) the subject of studying will not apply to the category of "monosubjects", it will be considered "integrated", but will be studied as a single subject unity (Martynova, 2016, p. 65).

A vast amount of publications have appeared in recent years documenting any on the integrated approach to teaching. For example, Pigdon \& Woolley (1992) state:

"An integrated approach allows learners to explore, gather, process, refine and present information about topics they want to investigate without the constraints imposed by traditional subject barriers." (p.1)

An integrated approach allows students to engage in purposeful, relevant learning. Integrated learning encourages students to see the interconnectedness and interrelationships between the curriculum areas. Rather than focusing on learning in isolated curriculum areas, an integrated program is based on skill development around a particular theme that is relevant to the students in the class. In an integrated curriculum unit, all activities contain opportunities for students to learn more about the content. Smith \& Ellery (1997) agree with this statement, saying that a deeper understanding of content through a range of purposeful activities can be developed through integrated teaching. Shoemaker (1989) adds that through integrative education, educators seek to improve students' basic skills in language arts and mathematics while also teaching thinking skills, physical and sensing skills and social skills. According to Gavelek et al., (2000), integrative approach to instruction addresses three needs in education: authenticity, meaningfulness, and efficiency.

\section{My context}

Within this work, we offer to integrate such professional economic discipline as "Microeconomics" into the discipline "Foreign Language (English)". "Foreign Language" is a subject that has no semantic content, it has only a specific linguistic system, not universal but typical only for the definite language. Not being a carrier of some definite meaning, it easily adapts to the expression of any monosubject or integrated subject which is going to be studied. Considering that any subject needs mastering, which means getting acquainted with its terminology database, interpreting its laws by means of studying the special literature, listening to lectures, practical work doing, etc., the language which serves for fulfilling these actions is learned simultaneously too. Namely, we study the corresponding terminological words; on their basis, the professional texts are created and learned; the same professional material, only in an extended form, is listened to at the lectures; the exercises for practising the material which was learned are done.

The introduction of integrative approach in the educational process of higher educational economic establishments will allow the students to acquire professional knowledge more effectively, the teachers to focus on the presentation of the basic material based on the concepts already learned at the lessons of other disciplines, to consider certain professional points at different angles; to consider best practices of training specialists in international economic institutions.

For integrated education, as it was mentioned above, we have chosen a professional discipline "Microeconomics", which is taught at the specialities 6030508 "Finance and Credit" and 6030509 "Accounting and Auditing" and students are provided with 144 academic hours.

For singling out this economic discipline, we analysed the curricula of the British, French, German and Ukrainian economic schools and universities, and found out subject "Microeconomics" was under study in all of them. It is included in the list of mandatory core subjects of economic high schools and we have chosen it as an example of content and language integrated teaching a professional discipline and a foreign language subject. This is determined by the fact that microeconomics is a part of the economic theory in general, its important section, where the economic relations of people, their economic behaviour and activities are studied. The study of microeconomics provides answers to many questions related to the problems of individual choice of the company's development strategy, which will allow its director to organise production scientifically grounded, to receive and distribute profits, as well as to be competitive at the labour market. These and many other economic problems are topical nowadays and require the specialists' attention all over the world. That is why their decision should be carried out in the same international language - namely English.

Speaking about professional knowledge and skills that students are to master, they must meet the requirements of future specialty, their functional responsibilities. In the aspect of our study we understand the professional knowledge as a systematic set of concepts and ideas about microeconomics as an important socio-economic phenomenon, namely: 1) the role and place of microeconomics in the world economic 
system; 2) basic categories and concepts of microeconomics theory; 3 ) laws and features of modern economy functioning at the microlevel; 4) principles of forming economic policy at the microlevel; 5) the content and guidelines of the developed and implemented economic policy of the enterprise; 6) basic models of describing the behaviour of firms at the market of perfect and imperfect competition; 7) laws of the market operating and means of its regulation; 8) dynamics of market relations.

The professional skills in this discipline are the following: 1) to describe economic processes and phenomena, 2) to characterise the production processes; 3) to explain the feasibility of doing some marketing moves, 4) to analyse the market situation; 5) to conduct the analysis of the proposed solutions of economic problems and to identify the best option; 6) to carry out financial forecasting at the microlevel; 7) to plan different kinds of professional (financial) activities; 8) to model the variations of the future economic development of the enterprise in terms of standard and modified conditions; 9) to describe and explain the presented digital and graphic information of some economic indicators; 10) to resolve problems related to professional activities.

In the aspect of content and language integrated teaching two disciplines, the above-mentioned knowledge and skills are acquired not only in the mother tongue, but in a foreign language, that promotes the application of a professional material in a foreign language. And we can state integrated educational process is the most effective one both for mastering professional content, and for learning a foreign language in a non-linguistic environment.

The fact, that the form of expression of a foreign language professional content is difficult for learners, indicates that this form requires multiple repetitions, reading and discussion of the material under study for its fluent use. And this, in its turn, leads not only to keeping in mind the professional information, but to its deep comprehension. Moreover, within our conception, any new content is studied on the basis of sound knowledge of the previous material and in a tight connection with it. That is why the professional subject in an integrated process gets the chance to be learned better.

As for a foreign language, we can state that for its learning in the non-linguistic environment the best variant is connected with an integrated educational process in which a foreign language doesn't fulfill the function of an educational, artificial, unnatural type of speaking but it has the function of solving complex, vital, professional problems. That's why in the end it gets its real-speech application similar to a mother tongue.

At the same time, the linguistic content of speech acts is determined by the semantic content of the professional subject, and the methods of foreign language speech skills development are coordinated with the methods of studying the key subject. This can be: an introduction and interpretation of new professional terms but these actions should be obligatory done in a foreign language; lecture presentation of the essence of the studied laws or phenomena but it also should be done in a foreign language; a check of comprehension of the presented professional information by answering the questions or by doing tests but - in a foreign language; perfecting professional knowledge by means of reading the texts with theoretical items in them and solving the corresponding professional problems but also everything should be done in a foreign language.

However, we understand that to speak fluently a foreign language only on the basis of linguistic knowledge and speech skills acquired in the non-linguistic universities is practically impossible. In this connection we offer a stage-by-stage increasing a potential of the foreign language speech for its effortless application in the process of learning any professional subjects.

The integrated process of teaching two diverse subjects, one of which is substantial and therefore dominant, and the other is contentless and therefore the auxiliary, should include mastering the conceptual apparatus of the first subject, and lexical and grammatical means of the second subject. And we should emphasise on learning particularly those lexical and grammatical means with the help of which the concepts of the main discipline are expressed.

The continuation of the integrated educational process of the same two diverse subjects should include mastering the theoretical knowledge of the first subject with the help of lexical and grammatical means of the second subject that will allow students to acquire simultaneously the basics of their profession and the ability to perceive, interpret, express and analyse professional information in a foreign language.

The completion of an integrated educational process of the same two diverse subjects should include practical application of the theoretical professional knowledge in a foreign language. This will encourage students to simultaneous usage and improvement of professional and foreign language speech skills which were acquired during procedural integration.

Thus, for the organisation of integrated educational process of two diverse subjects, we offer to subordinate the selection of foreign language linguistic material and its content to the theoretical economic material under study. Due to the fact that any professional course is divided into meaningful elements by the 
specialists, so the volume of the foreign language material and its content should match each part of the professional course content.

\section{The elements of the integrated educational process}

From classical didactics, it is known that any methodology depends on the educational objectives, and they, in their turn, depend on the elements of the subject of study, which correspond to the components of teaching content and are implemented by means of specific teaching methods. Implementation of teaching methods appears to be more effective if the teaching methods are accompanied by appropriate means of teaching. And the last link of any educational process is the control of its results. Hence there is a need to consider in more detail all the teaching elements of the integrated educational process.

Synthesised educational objectives. The synthesis of the educational objectives consists of planning the mastering of each part of the professional material by means of planning the mastering of the corresponding part of the foreign language material. Speaking about the subject of our study, which means the development of foreign language skills in the professional field of economics, the synthesis of the educational objectives will embrace the development of the ability to perform gradually increasing professional activities by means of a foreign language.

Synthesised elements of the subjects of study. The synthesis of the elements of two subjects of study involves singling out the parts of the professional material, which according to their contents relate to the parts of the foreign language material. Speaking about the subject of our study, the synthesis of the elements of the subjects of study will have its display in the English text with economic content that will correspond to the economic information existing in the students' minds.

Synthesised components of the teaching content. The synthesis of the components of the teaching content of two subjects takes place when acquiring professional knowledge and professional skills by means of acquiring knowledge, skills and abilities of foreign language speech activity. Taking into account the subject of our research, the synthesis of the components of the teaching content of two subjects will consist in acquiring the economic knowledge and skills by means of acquiring the English lexical and grammatical knowledge and skills to implement them into practice, that will ensure mastering the corresponding economic knowledge and skills.

Synthesised teaching methods. The synthesis of teaching methods of two subjects consists in performing the same actions for acquiring knowledge and skills of both professional speech activity and a foreign language activity. Taking into account the subject of our study methods of teaching professional representation of economic information by means of a foreign language will consist in doing the identical exercises in different kinds of activities: economic and foreign-language.

Synthesised teaching aids. The synthesis of teaching aids of two different subjects embraces using the identical aids to acquire knowledge and skills in professional and foreign language speech activities. Speaking about the subject of our research the synthesis involves the use of identical teaching aids to acquire knowledge and skills in economic and English language speech activities.

Synthesised control of educational results. The synthesis of control of educational results is in determining the growth of professional and foreign language skills and knowledge after learning the definite part of the professional and foreign language material.

The above-mentioned synthesized elements of teaching processes of two subjects "Microeconomics" and "Foreign Language" allow coming to conclusion that as a result there will be a synthesis of two educational processes into one common procedural unity, and it will allow the simultaneous acquisition of knowledge and development of skills in two kinds of activities: professional and foreign language ones.

\section{Stages of the content and language integrated teaching process}

There are three stages of the integrated process of teaching two subjects which were singled out by us.

At the first - linguistic and terminological - stage a foreign language speech activity dominates over the professional one. The acquisition of foreign language material knowledge, the formation of foreign language vocabulary and development of grammar skills which are necessary for further work with foreign language professional material take place.

At the second stage - informative and communicative - the equalisation of two kinds of activity takes place. Here a professionally-oriented text in a foreign language is introduced and an elaborated complex of tasks for work with this text is carried out. The work is aimed at learning the professional content of the text and at the same time at improving foreign language skills.

At the last - foreign-language and operative - stage the professional activity dominates over the foreign language speech activity. A foreign language only serves professional actions that are carried out both in 
standard and non-standard production conditions. All professional activities at this stage are planned, implemented and evaluated by means of a foreign language.

It is of primary importance to note that every successive foreign language speech skill is developed on the basis of the formation of the previous one, and the basic speech skill is based on mastering a certain dose of a linguistic material, providing foreign language speech activity.

\section{Conclusion}

Summarising the information collected, it can be concluded that to become an expert who can successfully compete at the international labour market students must simultaneously acquire knowledge and skills in two kinds of activities: professional and foreign language ones. The stages of such content and language integrated teaching which were singled out by us at the educational process are the following: linguistic and terminological, informative and communicative, foreign language and operative. The synthesised elements of the integrated educational process include synthesised educational objectives, elements of the subjects of study, components of the teaching content, teaching methods and control of educational results. All of them contribute to the simultaneous acquisition of knowledge and development of skills in two kinds of activities: professional and foreign language ones.

The next stage of our study will be experimental confirmation of our theoretical analysis of the problem of content and language integrated teaching Ukrainian university students majoring in economics.

\section{References:}

Doraisamy, R., Radhakrishnan, S. (2013). The effectiveness of integrated teaching over traditional teaching among first year MBBS students: A preliminary Study. Med J DY Patil Univ, 6, 139-41. https://doi.org/10.4103/0975-2870.110296

Gavelek, J. R., Raphael, T. E., Biondo, S. M., \& Wang, D. (2000). Integrated Literacy Instruction: In M. L.Kamil, P.B. Mosenthal, P.D. Pearson, \& R. Barr (Eds.). Handbook of reading research. Mahwah, NJ: Erlbaum (pp. 587-607).

Graaf, P. W., Wright, G., Walker, M. J. \& Welch, T. B. An Integrated Approach to Teaching Engineering Courses, in Proceedings of the ASEE Annual Conference, (Seattle, Washington), June 1998. Paper 1232-05.

Hannon, C. \& Clark, J. (2006). A Cognitive-Based Approach to Learning Integrated Language Components. The Third International Workshop on Natural Language Understanding and Cognitive Science. Paphos, Cyprus. https://doi.org/10.5220/0002503600270036

Jamkar, A. V., Yemul, V. L., \& Singh, G. (2016). Integrated teaching program with student-centred case base learning for undergraduates at B J Medical College Pune. https://doi.org/10.1111/j.1365-2929.2006.02438.x

Jennings, T. E. (1997). Restructuring for integrative education: multiple perspectives, multiple contexts. Westport, Conn: Bergin \& Garvey.

Klein, J. T. (1996). Crossing boundaries: knowledge, disciplinarities, and interdisciplinarities: University Press of Virginia.

Pigdon, K. \& Woolley, M. (1992). The Big Picture. Chap. 1 - 3. Victoria: Eleanor Curtain Publishing.

Shi, Y. (2016). Research on integrated education mode in college English teaching. SHS Web of Conferences 5, 01012. https://doi.org/10.1051/shsconf/20162501012

Shoemaker, B. (1989). Integrative Education: A curriculum for the Twenty-First Century. Oregon School Study Council 33/2.

Smith, J. W. A. and Ellery, W. (1997). How children learn to write. Auckland: Longman.

Toppo, N. A. et al. (2016). Introduction of Integrated Teaching Learning Module in Second M.B.B.S. Curriculum. Available online at: $\quad$ http://www.ijcmr.com/uploads/7/7/4/6/77464738/introduction_of_integrated_teaching second_m.b.b.s._curriculum_.pdf

Bezrukova, V. S. (1990). Pedagogicheskaya integratsiya: sushchnost', sostav, mekhanizmy realizatsii [Educational integration: the nature, composition, mechanisms for implementation]. Sverdlovsk, Russia.

Fedorets, G. F. (1989). Problemy integratsii v teorii i praktike obucheniya. [Integration problems in the theory and practice of teaching]. Leningrad, Russia: Leningrad state pedagogical institute.

Honcharenko, S. U. (1994). Integratsiya nauchnykh znaniy i problema soderzhaniya obrazovaniya. [Integration of scientific knowledge and the problem of educational conten]. Postmetodyka, 2 (b), 2-4.

Lednev, V. S. (1989). Soderzhaniye obrazovaniya [The content of education]. Moscow, Russia: Vysshaya shkola.

Levchik, I.Yu. (2014). Kompleks uprazhneniy dlya razvitiya pervichnogo rechevogo umeniya $v$ ramkakh formirovaniya professional'no oriyentirovannoy angloyazychnoy kompetentnosti $v$ govorenii budushchikh psikhologov [A set of exercises for the development of primary speech skills within the formation of professional English-language competence in speaking of the future psychologists]. Universum: Psychology and Education, 4(5). Available online at: http://7universum.com/ru/psy/archive/item/1211

Martynova, R. Yu. (2010). Types of integrated educational processes of professional activity of non-linguistic students, Naukoviy vísnik PNPU im. K. Ushinskoho (Odessa), 9, 80-88.

Martynova, R. Yu. (2016). Psikhologicheskiye osnovy integrirovannogo protsessa obucheniya obrazovatel'noy i inoyazychnoy rechevoy deyatel'nosti studentov neyazykovykh spetsial'nostey [Psychological bases of integrated training process of educational and foreign language speech activity of non-linguistic students]. Odessa, Ukraine: Osvita Ukraina.

Martynova, R. Yu. \& Dobrovolska, L. S. Psychological characteristics of linguistic and communicative stages of procedural integration of professional and foreign language speech activity. Nauka i osvita, 2, 32-41.

Mytnyk, M. M. (2014). Psikhologo-lingvisticheskiye osobennosti porozhdeniya inoyazychnoy prezentatsionnoy rechi budushchikh spetsialistov sfery turizma [Psycho-linguistic features of foreign language presentation speech generation of future tourism professionals]. Universum: Psychology and Education, 4 (5). Retrieved from http://7universum.com/ru/psy/archive/item/1213

Petrovsky, A. V. (1995). Vvedeniye v psikhologiyu [Introduction to Psychology]. Moscow, Russia: Publishing Centre "Academy".

Popel, O. V. (2015). Innovatsionnaya metodika obucheniya prezentatsii na angliyskom yazyke budushchikh inzhenerov 
[Innovative methods of teaching English Language Presentation to Future Engineers]. Oxford Review of Education and Science, 1(9), $579-585$.

Sova, M. O. (2005). Intehratsiya khudozhn'o-kul'turolohichnykh znan' u systemi profesiynoyi pidhotovky vchytelya humanitarnykh dystsyplin [The integration of artistic and cultural knowledge in the system of professional training of humanities teachers]. Extended abstract of candidate's thesis, Kiev, Ukraine. Retrieved from http://irbis-nbuv.gov.ua/cgibin/irbis64r 81/cgiirbis 64.exe

Talyzina N. F. (1984). Upravleniye protsessom usvoyeniya znaniy (psikhologicheskiye osnovy) [Control of learning process (psychological basis)]. Moscow, Russia: Publisher Moscow University.

Tarnopolsky, O. \& Kornieva, Z. (2013). Integracija obuchenija jazyku i special'nosti v nejazykovom vuze [The Integration of Teaching Language and Speciality in Non-linguistic Higher Educational Institution.]. Saarbrucken, Germany: LAP LAMBERT, Academic Publishing.

Tyunnikov, Yu. S. (1988). Metodika vyyavleniya i opisaniya integrativnykh protsessov v uchebno-vospitatel'noy rabote SPTU [Methods of identification and description of the integrative processes in the educational work of the vocational school]. Moscow, Russia: Publishing House APN USSR.

Zverev, I. \& Maksimova, V. (1981). Mezhpredmetnyye svyazi v sovremennoy shkole. [Interdisciplinary connections in the modern school]. Moscow, Russia: Pedagogy.

Zyazyun, I. A. (2008). Filosofiya pedahohichnoyi diyi [Philosophy of pedagogical action]. Cherkasy, Ukraine: Vydavnychyi viddil CHNU im. Bohdana Khmelnytskoho. 